\title{
Prognostic value of C-Reactive Protein / Albumin Ratio and Coronary Artery Disease Severity in Patients with Chronic Coronary Syndromes
}

\author{
Usama Mohamed Abd Elaal ${ }^{1}$, Ahmed Mohamed Boghdady ${ }^{2}$, Mohamed Shehab \\ Ahmed $^{1}$ and Alaa Ahmed Ghaleb ${ }^{1}$ \\ ${ }^{1}$ Department of Internal Medicine, Faculty of Medicine, Sohag University, Sohag, Egypt. \\ ${ }^{2}$ Department of cardiology, Faculty of Medicine, Sohag University, Sohag, Egypt.
}

E-mail : alaaghalib10@yahoo.com Tel : +20 1003045752

\begin{abstract}
:
Background: Syntax score (SS), which is an angiographic technique used in categorizing the severity of coronary artery disease (CAD), has a significant prognosis in coronary artery disease (CAD) and explain important information concerning the selection of revascularization policy. C-reactive protein (CRP) and albumin are markers of inflammation, and high levels of them are associated with high SS.

Aim of the Work: To detect whether baseline CRP to albumin ratio (CAR), an easily available and novel inflammatory indicator, is associated with SS in patients with chronic coronary syndromes.

Methodology: This study was carried out on 100 patients having chronic coronary syndromes for whom, a diagnostic coronary angiography was done at Sohag University Cath. Lab unit in the period from January -July 2021. Patients were divided randomly into two equal groups:

*Group I, patients having low SS $(\leq 22)$.

*Group II, patients having intermediate-high SS (>22).

Results: C-Reactive Protein/Albumin Ratio was significantly higher in patients having intermediate-high SS group $(P<.0001)$. In multivariate regression analysis, CAR was an independent indicator of intermediate-high SS group together with LDL. Conclusion: CAR was more intensely related to the severity of CAD than CRP and albumin alone and was detected to be an independent indicator for intermediate- high SS group.
\end{abstract}

Key Words: Albumin, coronary artery disease severity, C-reactive protein, C-reactive protein/albumin ratio, chronic coronary syndromes, syntax score.

Receive Date : 31/7/2021

Accept Date: 21/8/2021

Publish Date : 1/9/2021

\section{Introduction}

Coronary artery disease (CAD), is the principal reason for deaths worldwide, resulting in a huge economic burden on healthcare systems [1]. It is mainly due to atherosclerosis [2]. The inflammatory process has a role in the pathogenesis of atherosclerosis [3]. The acute phase reactants (APRs) can be used to assess the inflammatory state. It includes, C-reactive protein (CRP) and albumin, accompanying 
the presence of CAD, its severity, and cardiovascular complications [4]. Serum albumin has many anti-inflammatory, antioxidant properties and antiplatelet effects. It has an important role in the fluid exchange through the vessels wall [5]. Serum albumin level was independently related to the progress of various damaging conditions such as coronary artery disease, heart failure, atrial fibrillation and stroke [6]. The available data about prognosis in severe illnesses and malignancies propose that $\mathrm{C}$ reactive protein/albumin ratio (CAR) reveals the balance between CRP and albumin levels and has a significant prognosis [6]. The syntax score (SS), an angiographic technique used to categorizing the severity of $\mathrm{CAD}$, is evaluated depending on the coronary anatomy and severity of lesions [7]. Clinical studies revealed that SS has a significant prognosis in CAD and offers important information concerning the selection of revascularization policy [8]. The relationship between CAR and the severity of CAD is unknown. As CAD is an important inflammatory disease, CAR could be related to the extent of CAD as calculated by SS [1], [9].

\section{Methodology:}

A cross-sectional study in Cath. lab unit, Internal Medicine Department, Sohag University Hospitals, Egypt.

Patients: This study was carried out on 100 patients having a chronic coronary syndrome, for whom, a diagnostic coronary angiography was done at Sohag University Cath. Lab unit in the period from January -July 2021. Patients were classified randomly into two equal groups:

*Group I, patients having low SS $(\leq 22)$.

*Group II, patients having intermediate-high SS (>22).

Inclusion criteria: Patients (age more than 18 years old) with chronic coronary syndromes.

\section{Exclusion criteria:}

- Patients with previous history of CABG or PCI.

- Syntax score $=0$

- Active infection.

- Malignancy.

- Connective tissue disorders.

- Pregnancy.

- Severe co-morbidities.

Procedure: All patients were subjected to:

1. Full history:

- Personal history: age and sex.

- History of the risk factor of CAD as smoking, DM and hypertension. 
- Family history of IHD.

2. Detailed clinical examination.

3. Investigations:

- Hemoglobin levels.

- Creatinine.

- $\quad$ Lipid profile (TC, LDL-C , HDL-C)

- Albumin.

- CRP.

- CAR was calculated by multiplying the ratio of CRP to the albumin level by 100 .

- Echocardiography

\section{$\underline{\text { Statistical analysis }}$}

Data was manipulated using STATA version 14.2 (Stata Statistical Software: Release 14.2 College Station, TX: Stata Corp LP.). Quantitative data were presented as mean, median, standard deviation, and range. Qualitative ones were presented as percentages and number. Student t-test was used to compare the means of two groups. For data that were not normally distributed, Mann-Whitney test and Chi square test were used. . Odds ratios were calculated for logistic regression analysis. Graphs were designed using Excel program. P value was significant when less than 0.05.

\section{Ethical consideration:}

This study was approved by Scientific and Ethical committees of Sohag Faculty of Medicine.

Data gained from patients were used for scientific research and their confidentiality were kept.

A consent was obtained from all patients.

\section{Results:}

-As regarding the age of patients within the group I (patients having low SS) the mean age was $(55.12 \pm 3.49)$ years, while, group II (patients having high-intermediate SS) the mean age was $(59.72 \pm 3.43)$ years. The main difference between the groups was significant ( $\mathrm{p}$ value 0.0003 ).

-Regarding gender, in group I there were $40 \%$ of the studied patients were males and in group II there were $52 \%$ of them. (Table 1) 
Table (1) Comparison between patients having low versus those with highintermediate syntax scores as regard age and gender

\begin{tabular}{|l|c|c|c|}
\hline Variable & Low syntax scores & $\begin{array}{l}\text { High-intermediate } \\
\text { syntax scores } \\
\mathrm{N}=50\end{array}$ & P value \\
\hline Age/year & $\begin{array}{c}55.12 \pm 3.49 \\
\text { Mean } \pm \text { SD }\end{array}$ & $\begin{array}{c}59.72 \pm 3.43 \\
57.5(50: 64)\end{array}$ & 0.0003 \\
Median (range) & $30(60.00 \%)$ & $24(48.00 \%)$ & 0.23 \\
\hline Gender & $20(40.00 \%)$ & $26(52.00 \%)$ & \\
Females & & \\
Males & &
\end{tabular}

Regarding the risk factors, in group I, there was $32 \%$ of patients were diabetic, while, in group II there were $52 \%$ of patients were diabetic. There was a significant difference between the two groups ( $\mathrm{P}$ value 0.04 ).

-In group I, there was $38 \%$ of patients were hypertensive, while, group II there were $68 \%$. There was a significant difference between the two groups (P value 0.003 ).

-In group I, there was $44 \%$ of patients were smokers, while in group II there was about $32 \%$ of the patients were smokers. There was no a significant difference between the two groups (P value 0.22). (Table 2)

Table (2) Comparison between patients having low versus those with highintermediate syntax scores as regard medical history

\begin{tabular}{|l|r|r|c|}
\hline Variable & \multicolumn{1}{l|}{$\begin{array}{l}\text { Low syntax scores } \\
\mathrm{N}=50\end{array}$} & $\begin{array}{l}\text { High-intermediate } \\
\text { syntax scores } \\
\mathrm{N}=50\end{array}$ & P value \\
\hline $\begin{array}{l}\text { Diabetes mellitus } \\
\text { No }\end{array}$ & $\begin{array}{l}34(68.00 \%) \\
16(32.00 \%)\end{array}$ & $\begin{array}{r}24(48.00 \%) \\
26(52.00 \%)\end{array}$ & 0.04 \\
\hline Yes & $31(62.00 \%)$ & $16(32.00 \%)$ & 0.003 \\
Nypertension & $19(38.00 \%)$ & $34(68.00 \%)$ & \\
Yes & $28(56.00 \%)$ & $34(68.00 \%)$ & 0.22 \\
\hline $\begin{array}{l}\text { Smoking } \\
\text { No } \\
\text { Yes }\end{array}$ & $22(44.00 \%)$ & $16(32.00 \%)$ & \\
\hline
\end{tabular}

-As regarding Serum Cholesterol, in group I, the mean was $181.16 \pm 19.89 \mathrm{mg} / \mathrm{dl}$, while, group II the mean was $207.72 \pm 20.23 \mathrm{mg} / \mathrm{dl}$. The main difference between the groups was significant with $\mathrm{P}$ value $<0.0001$.

-As regarding Serum LDL, of group I, the mean was $93.12 \pm 8.85 \mathrm{mg} / \mathrm{dl}$, while, group II the mean was $112.24 \pm 18.93 \mathrm{mg} / \mathrm{dl}$. The main difference between the two groups was significant with $\mathrm{P}$ value $<0.0001$.

-As regarding Serum HDL, of group I, the mean was $48.32 \pm 5.68 \mathrm{mg} / \mathrm{dl}$, while, group II the mean was $53.74 \pm 5.47 \mathrm{mg} / \mathrm{dl}$. The main difference between the two groups was significant with $\mathrm{P}$ value $<0.0001$.

-Regarding EF, of group I, the mean was $55.88 \pm 3.42 \%$ while, in group II the mean 
was $50.88 \pm 3.45 \%$. The main difference between the groups was highly significant with $\mathrm{P}$ value $<0.0001$.

-As regarding CRP, of group I, the median was 0.10 (0.06:0.3) $\mathrm{mg} / \mathrm{dl}$, while, group II the median was $0.5(0.2: 0.9) \mathrm{mg} / \mathrm{dl}$. The main difference between the groups was highly significant with $\mathrm{P}$ value $<0.0001$.

-As regarding Albumin, of group I, the median was 3.7 (3.2:4.4) g/dl, while, group II the median was $3.4(2.9: 3.9) \mathrm{g} / \mathrm{dl}$. The main difference between the groups was highly significant with $\mathrm{P}$ value $<0.0001$.

-As regarding CAR (CRP/Alb ratio), of group I, the median was 2.41 (1.36:8.57), while, group II the median was 14.96 (5.26:30). The main difference between the groups was highly significant with $\mathrm{P}$ value $<0.0001$. (Table 3)

Table (3) Comparison between patients having low versus those with highintermediate syntax scores as regard investigation

\begin{tabular}{|c|c|c|c|}
\hline Variable & $\begin{array}{l}\text { Low syntax scores } \\
\qquad \mathrm{N}=50\end{array}$ & $\begin{array}{l}\text { High-intermediate } \\
\text { syntax scores } \\
\mathrm{N}=50 \\
\end{array}$ & P value \\
\hline $\begin{array}{l}\text { Creatinine }(\mathrm{mg} / \mathrm{dl}) \\
\text { Mean } \pm \text { SD } \\
\text { Median (range) }\end{array}$ & $\begin{array}{c}0.91 \pm 0.20 \\
0.9(0.6: 1.2)\end{array}$ & $\begin{array}{c}0.88 \pm 0.20 \\
0.9(0.6: 1.2)\end{array}$ & 0.40 \\
\hline $\begin{array}{l}\text { Hemoglobin }(\mathrm{g} / \mathrm{dl}) \\
\text { Mean } \pm \text { SD } \\
\text { Median (range) } \\
\end{array}$ & $\begin{array}{l}10.32 \pm 1.60 \\
10.5(8: 13) \\
\end{array}$ & $\begin{array}{c}11.0 \pm 1.03 \\
11.0(9.6: 12.8) \\
\end{array}$ & 0.01 \\
\hline $\begin{array}{l}\text { Total cholesterol }(\mathrm{mg} / \mathrm{dl}) \\
\text { Mean } \pm \text { SD } \\
\text { Median (range) }\end{array}$ & $\begin{array}{l}181.16 \pm 19.89 \\
186(155: 210)\end{array}$ & $\begin{array}{c}207.72 \pm 20.23 \\
200.5(175: 240)\end{array}$ & $<0.0001$ \\
\hline $\begin{array}{l}\text { LDL-C }(\mathrm{mg} / \mathrm{dl}) \\
\text { Mean } \pm \text { SD } \\
\text { Median (range) }\end{array}$ & $\begin{array}{c}93.12 \pm 8.85 \\
92.5(80: 106) \\
\end{array}$ & $\begin{array}{c}112.24 \pm 18.93 \\
115(86: 140) \\
\end{array}$ & $<0.0001$ \\
\hline $\begin{array}{l}\text { HDL-C }(\mathrm{mg} / \mathrm{dl}) \\
\text { Mean } \pm \text { SD } \\
\text { Median (range) }\end{array}$ & $\begin{array}{c}48.32 \pm 5.68 \\
49(40: 57) \\
\end{array}$ & $\begin{array}{r}53.74 \pm 5.47 \\
53(45: 62) \\
\end{array}$ & $<0.0001$ \\
\hline $\begin{array}{l}\text { EF }(\%) \\
\text { Mean } \pm \text { SD } \\
\text { Median (range) } \\
\end{array}$ & $\begin{array}{c}55.88 \pm 3.42 \\
54.5(52: 62) \\
\end{array}$ & $\begin{array}{c}50.88 \pm 3.45 \\
52(45: 55) \\
\end{array}$ & $<0.0001$ \\
\hline $\begin{array}{l}\text { C-reactive protein }(\mathrm{CRP})(\mathrm{mg} / \mathrm{dl}) \\
\text { Mean } \pm \text { SD } \\
\text { Median (range) }\end{array}$ & $\begin{array}{c}0.12 \pm 0.08 \\
0.10(0.06: 0.3)\end{array}$ & $\begin{array}{c}0.53 \pm 0.21 \\
0.5(0.2: 0.9) \\
\end{array}$ & $<0.0001$ \\
\hline $\begin{array}{l}\text { Serum albumin }(\mathrm{g} / \mathrm{dl}) \\
\text { Mean } \pm \text { SD } \\
\text { Median (range) }\end{array}$ & $\begin{array}{c}3.81 \pm 0.37 \\
3.7(3.2: 4.4) \\
\end{array}$ & $\begin{array}{c}3.35 \pm 0.33 \\
3.4(2.9: 3.9) \\
\end{array}$ & $<0.0001$ \\
\hline $\begin{array}{l}\text { CRP/albumin ratio } \\
\text { Mean } \pm \text { SD } \\
\text { Median (range) }\end{array}$ & $\begin{array}{c}3.23 \pm 1.98 \\
2.41(1.36: 8.57)\end{array}$ & $\begin{array}{c}16.15 \pm 6.35 \\
14.96(5.26: 30) \\
\end{array}$ & $<0.0001$ \\
\hline
\end{tabular}

In this study, multivariate regression analysis, CAR revealed an independent predictor of intermediate-high SS group together with LDL with a statistically significant difference. (Table 4,5) 
Table (4) Multivariate analysis of factors predicting high-intermediate syntax scores (include significant factors in univariate)

\begin{tabular}{|l|l|l|}
\hline Variable & Odds ratio (95\% confidence interval) & P value \\
\hline Age/year & $2.06(0.46: 9.18)$ & 0.34 \\
\hline Diabetes mellitus & $11.98(0.2: 68.71)$ & 0.23 \\
\hline Hypertension & $0.44(0.02: 12.44)$ & 0.63 \\
\hline Hemoglobin $(\mathrm{g} / \mathrm{dl})$ & $1.55(0.58: 4.14)$ & 0.38 \\
\hline Total cholesterol $(\mathrm{mg} / \mathrm{dl})$ & $1.03(0.92: 1.19)$ & 0.34 \\
\hline LDL-C $(\mathrm{mg} / \mathrm{dl})$ & $1.22(1.001: 1.48)$ & 0.048 \\
\hline HDL-C $(\mathrm{mg} / \mathrm{dl})$ & $1.003(0.74: 1.36)$ & 0.98 \\
\hline CRP/albumin ratio & $4.90(1.09: 22.06)$ & 0.038 \\
\hline
\end{tabular}

Table (5) Final multivariate analysis of factors predicting high-intermediate syntax scores

\begin{tabular}{|l|c|c|}
\hline Variable & Odds ratio (95\% confidence interval) & P value \\
\hline LDL-C $(\mathrm{mg} / \mathrm{dl})$ & $1.23(1.02: 1.49)$ & 0.03 \\
\hline CRP/albumin ratio & $3.36(1.43: 7.90)$ & 0.005 \\
\hline
\end{tabular}

Correlation between Age, Creatinine, Hemoglobin, TC, LDL-C, HDL-C, CRP/ Albumin ratio, CRP, Albumin and high syntax score showed statistically significant differences with all while non-significant with Creatinine. (Table 6)

Table (6) Correlation between syntax score and different variables

\begin{tabular}{|l|c|c|}
\hline Variable & Correlation co-efficient & P value \\
\hline Age/year & 0.41 & $<0.0001$ \\
\hline Creatinine (mg/dl) & $\mathbf{- 0 . 1 4}$ & 0.18 \\
\hline Hemoglobin $(\mathrm{g} / \mathrm{dl})$ & $\mathbf{0 . 2 6}$ & $\mathbf{0 . 0 0 8}$ \\
\hline Total cholesterol (mg/dl) & $\mathbf{0 . 4 8}$ & $<0.0001$ \\
\hline LDLC (mg/dl) & $\mathbf{0 . 4 3}$ & $<0.0001$ \\
\hline HDLC (mg/dl) & $\mathbf{0 . 3 2}$ & $\mathbf{0 . 0 0 1}$ \\
\hline C-reactive protein & $\mathbf{0 . 7 5}$ & $<\mathbf{0 . 0 0 0 1}$ \\
\hline Serum albumin & $\mathbf{- 0 . 4 7}$ & $<0.0001$ \\
\hline CRP/albumin ratio & $\mathbf{0 . 7 6}$ & $<0.0001$ \\
\hline
\end{tabular}

\section{Discussion:}

The SS refers to the quantity and the site of the lesion in the coronary artery and thus refers to the myocardium at risk for ischemia. High SS is mostly a sign of a high degree of atherosclerosis in the coronary artery that relates to severe complications and poor prognosis [10]. Numerous studies were conducted using the syntax trial had approved that SS was an independent predictor of short-and long-term morbidity and mortality and poor cardiovascular results in a large number of patients, including chronic coronary syndrome [11]. Evaluation of high SS may have a good impact on the treatment of these patients. In this study, increased levels of LDL-C, and CAR were found to be independent indicators of intermediate-high SS in patients having chronic cardiovascular diseases. 
- The main difference between the two groups regarding age was significant ( $\mathrm{p}$ value 0.0003 ). While regarding gender it was not significant ( $\mathrm{p}$ value 0.23 ). Yahagi, $\mathrm{K}$ et al., (2015) [12] reported that most of the fundamental risk factors for coronary artery disease were similar between males and females. However, the influence of numerous risk factors was different between males and females, with smoking being more risky in females than males, especially in younger ones. Furthermore, the impact of menopause was also significant in females: incidence of plaque rupture is higher in older females as compared to younger.

-In this study, regarding risk factors, There was a significant difference between the two groups regards the presence of diabetes, hypertension and smoking status ( $\mathrm{P}$ value $=0.04,0.003$ and 0.22). A study by Oh et al. (2017) [13] indicated that hypertension was commonly associated with comorbidity. On the other hand, Suzuki et al. (2019) study included 204 patients (mean age, 72 years; male, 69\%) and detected that there was no significant difference among all patients regarding the risk factors.

-In this study, the main difference between the two groups regards the serum cholesterol, serum LDL and serum HDL were significant $(\mathrm{P}$ value $=<0.0001,<$ 0.0001 and $<0.0001)$.

These results were concordant with Suzuki et al. (2019) [14] which reported that there was a significant difference regarding total cholesterol and LDL, with a nonsignificant difference as regard HDL. On contrary, Duman et al. (2019) [15] reported that there was no significant difference regarding LDL and HDL.

-As regarding CRP, Albumin CAR (CRP/Alb ratio) between the groups, the difference were highly significant $(\mathrm{P}$ value $=<0.0001,<0.0001,<0.0001)$. CRP and SA indicators are commonly used in medical practice. Serum CRP, an acute phase protein from the liver, is increased due to inflammation. Koenig W. (2013) [16] Also, increased CRP levels were related to the severity of coronary artery in patients with the chronic coronary syndrome. Pan HC, et al (2015) [17] and Karabağ et al. (2018) [1], reported that patients having stable angina pectoris, for whom a diagnostic coronary angiography was done for suspected CAD, have a high significant difference regarding CRP between the high and low SS groups. Also, Kayapinar et al. (2019) [18] had revealed the same findings regarding hs-CRP. CRP was related to damage of endothelial progenitor cells, damage fibrinolysis, elevate collagen degradation in monocytes, stimulate the complement system, and may be related to the uptake of LDL-C by macrophages [19]. Low level of albumin level may be related to high risk of morbidity and mortality in multiple cardiovascular diseases [20]. Kurtul and colleagues reported that low level of albumin is an independent indicator of high SS and in-hospital deaths in patients having the acute coronary syndrome [4]. Low level of albumin is an inflammatory condition associated with chronic diseases [21]. Also, low level of albumin was related to increased viscosity of blood, endothelial dysfunction, activate platelet and increase their aggregation, and enhance the formation of platelet mediators responsible for coronary artery stenosis. Karabağ et al. (2018) [1] reported that the relation between the level of albumin, CRP, and SS was 
the same as that concluded in the last studies. Including albumin and CRP into a single indicator was related to poor outcomes in multiple diseases like sepsis and cancer [22].

\section{Conclusion}

A high level of CAR was related to the severity of coronary atherosclerosis, evaluated by SS, in patients having chronic coronary syndromes. CAR was a more perfect indicator than CRP or albumin in recognition of the patient with high SS. And so, CAR evaluation can be used for early detection of the patients having chronic coronary syndromes in clinical practice.

\section{References:}

1- Karabağ, Y., Çağdaş, M., Rencuzogullari, I., Karakoyun, S., Artaç, İ., İliş, D., et al (2018): Relationship between C-reactive protein/albumin ratio and coronary artery disease severity in patients with stable angina pectoris. Jthnal of clinical laboratory analysis, 32(7): e22457.

2- Michelsen, M.M., Mygind, N.D., Pena, A., Aziz, A., Frestad, D., Høst, N. et al (2016): Peripheral reactive hyperemia index and coronary microvascular function in women with no obstructive CAD: the iPOWER study. JACC: Cardiovascular Imaging, 9(4): 411-417.

3- Poddar, K.L., Modi, D.K., Wayangankar, S., Thakkar, B., Krishnaswamy, A., Kumari, M., et al (2016): Two-decade trends in the prevalence of atherosclerotic risk factors, coronary plaque morphology, and outcomes in adults aged $\leq 45$ years undergoing percutaneous coronary intervention. The American Journal Of Cardiology, 118(7): 939943.

4- Kurtul, A., Murat, S.N., Yarlioglues, M., Duran, M., Ocek, A.H., Koseoglu, C., et al (2016): Usefulness of serum albumin concentration to predict high coronary SYNTAX score and in-hospital mortality in patients with acute coronary syndrome. Angiology, 67(1): 34-40.

5- Adach, W. and Olas, B. (2020): Carbon monoxide and its donors-their implications for medicine. Future Medicinal Chemistry, 11(1): 61-73.

6- Wu, J., Tan, W., Chen, L., Huang, Z. and Mai, S., (2018): Clinicopathologic and prognostic significance of $\mathrm{C}$-reactive protein/albumin ratio in patients with solid tumors: an updated systemic review and meta-analysis. Oncotarget, 9(17):13934.

7- Neumann, F.J., Sousa-Uva, M., Ahlsson, A., Alfonso, F., Banning, A.P., Benedetto, U., et al (2019): 2018 ESC/EACTS guidelines on myocardial revascularization. European Heart Journal, 40(2):.87-165.

8- Franzone, A., Taniwaki, M., Rigamonti, F., Heg, D.H., Piccolo, R., Roffi, M., et al (2016): Angiographic the severity of coronary artery disease according to SYNTAX score and clinical outcomes after revascularisation with newer-generation drug-eluting stents: a substudy of the BIOSCIENCE trial. EuroIntervention, 12(5): e595-604.

9- Kundu, A., Sardar, P., O'Day, K., Chatterjee, S., Owan, T. and Abbott, J.D., (2018): SYNTAX score and outcomes of coronary revascularization in diabetic patients. Current Cardiology Reports, 20(5)28-35. 
10- Caixeta A, Généreux P, Palmerini T, et al. Prognostic utility of the SYNTAX score in patients with single versus multivessel disease undergoing percutaneous coronary intervention (from the Acute Catheterization and Urgent Intervention Triage StrategY [ACUITY] trial). Am J Cardiol. 2014;113:203-210.

11- Garg S, Sarno G, Serruys PW, et al. Prediction of 1- year clinical outcomes using the SYNTAX score in patients with acute ST- segment elevation myocardial infarction undergoing primary percutaneous coronary intervention: a substudy of the STRATEGY (single high-dose bolus tirofiban and sirolimus- eluting stent versus abciximab and bare- metal stent in acute myocardial infarction) and MULTISTRATEGY (multicenter evaluation of single high- dose bolus tirofiban versus abciximab with sirolimus- eluting stent or bare- metal stent in acute myocardial infarction study) trials. JACC Cardiovasc Interv. 2011;4:66-75.

12- Yahagi, K., Davis, H.R., Arbustini, E. and Virmani, R., (2015): Sex differences in coronary artery disease: pathological observations. Atherosclerosis, 239(1): 260-267.

13- Oh, J., Kim, S.H., Park, K.N., Oh, S.H., Kim, Y.M., Kim, H.J. and Youn, C.S., (2017): High-sensitivity C-reactive protein/albumin ratio as a predictor of in-hospital mortality in older adults admitted to the emergency department. Clinical and Experimental Emergency Medicine, 4(1): 19-40.

14- Suzuki, S., Hashizume, N., Kanzaki, Y., Maruyama, T., Kozuka, A. and Yahikozawa, K., (2019): Prognostic significance of serum albumin in patients with stable coronary artery disease treated by percutaneous coronary intervention. Plos one, 14(7): 450-540.

15- Duman, H., Çinier, G., Bakırcı, E.M., Duman, H., Şimşek, Z., Hamur, H., et al (2019): Relationship between C-reactive protein to albumin ratio and thrombus burden in patients with acute coronary syndrome. Clinical and Applied Thrombosis/Hemostasis, 25: $10-40$.

16- Koenig W. High- sensitivity C- reactive protein and atherosclerotic disease: from improved risk prediction to risk- guided therapy. Int J Cardiol. 2013;168:5126-5134.

17- Pan HC, Sheu WH, Lee WJ, et al. Coronary severity score and C- reactive protein predict major adverse cardiovascular events in patients with stable coronary artery disease

(from the Taichung CAD study). Clin Chim Acta. 2015;445:93-100.

18- Kayapinar, O., Ozde, C. and Kaya, A., (2019): Relationship between the reciprocal change in inflammation-related biomarkers (Fibrinogen-to-Albumin and hsCRP-toAlbumin ratios) and the presence and severity of coronary slow flow. Clinical and Applied Thrombosis/Hemostasis, 25: 710-790.

19- Bisoendial RJ, Boekholdt SM, Vergeer M, Stroes ES, Kastelein JJ. C- reactive protein is a mediator of cardiovascular disease. Eur Heart J. 2010;31:2087-2091.

20- Murat SN, Kurtul A, Yarlioglues M. Impact of serum albumin levels on contrast- induced acute kidney injury in patients with acute coronary syndromes treated with percutaneous coronary intervention. Angiology. 2015;66:732-737.

21- Don BR, Kaysen G, eds. Poor nutritional status and inflammation: serum albumin: relationship to inflammation and nutrition. Seminars in dialysis; 2004: Wiley Online Library.

22- Ge X, Cao Y, Wang H, et al. Diagnostic accuracy of the postoperative ratio of Creactive protein to albumin for complications after colorectal surgery. World J Surg Oncol. 2017;15:15. 